\title{
Campaigning for the Labour Party but from the Outside and with Different Objectives: the Stance of the Socialist Party in the UK 2019 General Election
}

Faire campagne pour le parti travailliste mais depuis l'extérieur et avec des objectifs différents: la position du Socialist Party lors des elections législatives de 2019 au Royaume-Uni.

\section{Nicolas Sigoillot}

\section{(2) OpenEdition}

Journals

Édition électronique

URL : http://journals.openedition.org/rfcb/5873

DOI : $10.4000 /$ rfcb.5873

ISSN : 2429-4373

Éditeur

CRECIB - Centre de recherche et d'études en civilisation britannique

Référence électronique

Nicolas Sigoillot, « Campaigning for the Labour Party but from the Outside and with Different Objectives: the Stance of the Socialist Party in the UK 2019 General Election », Revue Française de Civilisation Britannique [En ligne], XXV-3 | 2020, mis en ligne le 10 septembre 2020, consulté le 10 septembre 2020. URL : http://journals.openedition.org/rfcb/5873; DOI : https://doi.org/10.4000/rfcb. 5873

Ce document a été généré automatiquement le 10 septembre 2020.

\section{c)}

Revue française de civilisation britannique est mis à disposition selon les termes de la licence Creative Commons Attribution - Pas d'Utilisation Commerciale - Pas de Modification 4.0 International. 


\section{Campaigning for the Labour Party but from the Outside and with Different Objectives: the Stance of the Socialist Party in the UK 2019 General Election}

Faire campagne pour le parti travailliste mais depuis l'extérieur et avec des objectifs différents: la position du Socialist Party lors des elections législatives de 2019 au Royaume-Uni.

Nicolas Sigoillot

\section{Introduction: Turning (back) to the Labour Party}

1 The link between the Socialist Party and the Labour Party has always been a problematic one. The Socialist Party is the heir of the second Revolutionary Socialist League, a Trotskyist entryist organisation founded in 1957 by Ted Grant and Jimmy Deane, two major actors of early British Trotskyism. This organisation acted from within the Labour Party and achieved a certain success as the Militant group from 1964 on. The political objective of Militant, like that of all deep entryist groups, was to elevate class consciousness within the Labour Movement by pushing forward socialist policies inside the main social-democratic organisation of the country, ${ }^{1}$ which, in the case of the United Kingdom, is the Labour Party. The theory behind this strategy comes from Lenin himself in 1920: at that time, he advised the newly born Communist Party of Great Britain to apply for affiliation to the Labour Party because it was, in effect, the party of the working class. ${ }^{2}$ The role of the communists, according to Lenin, was to support the Labour Party in the same manner a rope supports a hanged man. When the big split between the Trotskyists and the Stalinists happened around the world in the late 1920s - early 1930s, Trotsky himself recommended that its meagre forces in Britain 
infiltrate the Labour Party in 1934, in order to develop a revolutionary current within it. ${ }^{3}$

2 Militant's strategy, from its creation, was directly in line with Trotsky's 1934 recommendations. The aim of the entryist group was to push forward "transitional" socialist policies, to agitate the Labour movement so that when the time was ripe (readd: when capitalism is in crisis), the masses, educated to genuine socialist ideas - at the moment still inside the Labour Party - would break with this party and achieve a socialist revolution. That is why, since the late 1930 s or early 1940 s, the rallying slogan of all Trotskyists infiltrated within the Labour Party could be summed up as "Labour to power on socialist policies". ${ }^{4}$

3 Militant achieved tremendous success in the 1980s within the Labour Party: it was mostly responsible for its very radical 1983 election platform. Indeed, the group got three members of parliament elected and managed to gain effective control over Liverpool City Council. Militant was also at the origin of the Anti-Poll tax movement that contributed to the demise of Margaret Thatcher. After a long sequence of purges and witch-hunts organised by the executive committee of the Labour Party, Militant decided to leave the ship in 1992 under the name Militant Labour, an independent structure which renamed itself the Socialist Party in $1997 . .^{5}$

4 The line of the group changed and went from critical support of the Labour Party in 1992, either supporting Labour candidates to elections or presenting someone against them, to total opposition in 1997 with the mutation into the Socialist Party. Since then, Militant have participated in many coalitions to stand against Labour in elections: under the Socialist Alliance coalition from 1999, then under the Socialist Green Unity Coalition for the general election of 2005, in the 2009 European elections the party joined the No2EU coalition and the party went into the 2010 and 2015 general elections as a part of the Trade Unionist and Socialist Coalition, with a clear anti-Labour Party line. ${ }^{6}$

5 This all changed with the election of Jeremy Corbyn at the head of the Labour Party in 2015. While still in existence, TUSC presented no candidates in the 2017 general election against Corbyn's Labour Party and called for a critical support of the Labour Party candidates, to achieve a Labour Government.

6 The 2019 general election was in direct line with this strategy and the Socialist Party openly supported Jeremy Corbyn's Labour Party. As early as 2018, it started to push for a general election to bring Labour to Power. In a campaign leaflet entitled "Let's get the Tories out" and dating from the $27^{\text {th }}$ of November, the Socialist Party wrote:

The Socialist Party fully supports Jeremy Corbyn's anti-austerity stance. Since he was first elected as Labour leader, we have done all we can to strengthen the potential anti austerity party around Corbyn in its battle against the Blairite right of the Labour Party.7

7 This stance is to some extent a return to the early 1980s when Militant as well as other Trotskyist groups supported Tony Benn's leadership bid. This was the subject of many debates inside the Socialist Party but, in the end, 75 former members of Militant applied for readmittance to the Labour Party from which they had been expelled in the 1980s or 1990s. These are all signs that these Trotskyists returned to an idea of a struggle from within the Labour Party itself. Most of the literature produced by the Socialist Party since Jeremy Corbyn's election as a leader was aimed at recapturing the Labour Party from the Blairite right wing. This eventually led the Socialist Party to 
officially reapply for affiliation to the Labour Party on the $6^{\text {th }}$ of April 2018 through a letter written by Peter Taaffe, the party's general secretary.

I am writing to you on behalf of the Socialist Party (previously the Militant). We would like to meet with you to discuss the possibility of our becoming an affiliate of the Labour Party. From the beginning we have enthusiastically supported Jeremy Corbyn's election as leader of the Labour Party, which has offered the possibility of transforming Labour into a clear anti-austerity party, based on the trade unions and the working class. Clearly, your appointment as general secretary, replacing Iain McNicol, is an important step towards the renewal of the party along these lines. ${ }^{8}$

8 This idea had been unofficially discussed since the election of Corbyn in 2015, but was only starting to be raised in the official publications of the party from June 2017. ${ }^{9}$ The official point of focus of this strategy was not only to campaign for the party but also to fight the right wing within it. There always had been a focus on the defeat of the right wing of the Labour Party: it was already present in the Socialist Party's DNA back in 1949. The Labour Party wasalways interpreted by Trotskyists, especially early Trotskyists, as a party in tension between a bourgeois pro-capitalist right-wing bureaucracy and the workers in it. The elements that form the basis in this assumption are the fact that the Labour Party is the mass party of the working class in British politics, made by and linked with the trade unions. According to Ted Grant (the original founder of Militant), when the final crisis of capitalism comes, workers willinitially turn to the Labour Party, because they have not yet been entirely disillusioned by it. At this point, it will be the role of the revolutionaries who are inside it to educate and prepare the masses. Then, once the Labour Party, because of its bourgeois bureaucracy and pro-capitalist nature, fails at its task of solving the problems of the working class, the latter, thanks to the education of the revolutionaries, will turn away andfound a new mass revolutionary party. As such, the fight between the left-radical wing and the right wing is the central point of tension for the Trotskyists. Even though these plans were abandoned in the early 1990s after a decade of fighting with the National Executive of the Labour Party, ${ }^{10}$ they were brought back to the foreground with Corbyn's rise and the tenacity of the grassroots movement. The Socialist Party interpreted that surge of a new radical left wing as a breach in the domination of the Labour Party by its right since the 1980s, and tried to re-engage itself in the fight.

9 The attempt of the Socialist Party to reaffiliate was countered both by the Labour Party itself and by Momentum members that immediately saw this strategy as disruptive and felt it was aiming at taking control of the party. Jenny Formby, the Labour Party's general secretary, answered the request for affiliation by referring to clause II, part 5 of the first chapter of the constitution of the party explaining that:

Political organisations not affiliated or associated under a national agreement with the party, having their own programme, principles and policy, or distinctive and separate propaganda, or possessing branches in the constituencies, or engaged in the promotion of parliamentary or local government candidates, or having allegiance to any political organisation situated abroad, shall be ineligible for affiliation to the party. ${ }^{11}$

10 She further argued by explaining that the Socialist Party had stood candidates for the Council elections of May 2018. And, indeed, at that point the Socialist Party had been part of an electoral coalition named TUSC (Trade Unionist and Socialist Coalition) and had stood 111 candidates against Labour councillors. As such, the application was refused because the Socialist Party constituted, de facto, a rival organisation. Peter 
Taaffe answered the refusal by explaining that his party had stood against councillors opposed to Jeremy Corbyn's programme and who were practising budget cuts on local levels. Furthermore, the Socialist Party argued that they did not stand candidates against pro-Corbyn councillors. ${ }^{12}$

\section{Campaigning for or with the Labour Party}

The elections of 2019 were thus an important moment for the Socialist Party: they would determine the latter's approach to the Labour Party for the coming years. As such, the aim of this election for the Socialist Party was not whether there would be a radical left wing Corbyn led government, but rather if the Labour Party would prove a fertile ground for the maturation of revolutionary socialist ideas.

The failure of Corbyn and his line, both with the defeat at the general election of 2019 and with the defeat of his political heir, Rebecca Long-Bailey, at the leadership election of February to April 2020, gave the Socialist Party reason to distance themselves once more. The push for conditional support for the Labour Party was rapidly transformed into a call for the foundation of a revolutionary party of the radical left.

It would be incorrect to assume that this scenario was not widely anticipated by the Socialist Party even during the campaign. As early as 2015, the Socialist Party had characterised the Labour Party as two parties in one and, before the 2019 elections, Peter Taaffe had made a speech at the yearly Socialist Party Rally in London stating this:

We've said there's two or three parties in the Labour Party. How long can we continue with these saboteurs in the Labour Party?...The election will represent a dividing line between the past and the new situation that will open up in Britain. This is the music of the future, the music of Socialism. Exciting times lie ahead and capitalism cannot solve the problems of working people. We intend to seize every opportunity to build our forces forward to the building of a mass workers' party which the Socialist Party can become as part of the reorganisation and the regeneration of the mass movement in Britain. On that basis we'll be able to create a democratic and socialist world. ${ }^{13}$

This speech, made less than a month before the general election, proves that what was at stake here was the appropriate tactics to achieve a socialist revolution and not the winning or losing of an election. The aim of the election would have been to give the radical left a mandate and symbolic power; but with such a (hypothetical) victory, it would have been easier for socialists to fight the right wing publicly. In Trotskyist theory, there has always been an emphasis on the fact that traditional instances of parliamentary democracy in their current state can not bring real social change as they are pro-capitalist in nature. As such, the bringing to power of a radical left government would not have had any other objective than the exposition of the inability of the Labour Party to conduct social change. This exposition would have thus resulted in a turn to socialist policies by disillusioned electors of the Labour Party, which the Socialist Party would have been ready to welcome or to help find their way to the creation of a mass anticapitalist party. That is what Peter Taaffe means by the sentence "We intend to seize every opportunity to build our forces forward to the building of a mass workers party": the election was part of this set of opportunity. itself? Since the Socialist Party was not integrated in the campaign by the Labour Party, 
it decided to campaign on its own on behalf of the Labour Party. To do this it mobilised its activist network and deployed a vast arsenal of campaigning tools just as if it was officially campaigning. The party produced a manifesto entitled "Let's get the Tories out!" with a subtitle in the form of three slogans: "Defeat Johnson's Billionaire government. Corbyn can win with socialist policies. Build a mass anti-austerity movement". The manifesto in itself is interesting because it mentions "Socialist" twenty-two times while it mentions "Labour" only fifteen times showing thus that the priority of the manifesto was the promotion of socialist ideals rather than simply promoting the Labour Party. On top of the leaflet sits the Socialist Party logo next to the sentence "General Election 2019". The first page does not mention the Labour Party per se nor does it ask for a Labour government. However, along with some essential key points of the Labour Party manifesto (such as the scrapping of Universal Credit or the end of zero-hour contracts), it asks for "A socialist government to take into public ownership the top 150 companies that dominate the economy, and run them under democratic workers' control and management". The list of demands formulated by the Socialist Party in this manifesto constitutes what academics and Marxists would call "transitional demands". The theory behind transitional demands are that they are to act as a bridge between partial (or minimal) demands, in other words reforms, and the maximum program, in other words the establishment of communism and workers' democracy. The nature of a transitional demand is to be realistic but doomed to fail in its implementation by social democracy. They should take into account the current situation of the workers and create a basis around which they might fight, such as a large number of nationalisations, the reduction of working time, better wages and pensions. These demands are meant to raise the political consciousness of the working class and drive them towards a genuine socialist objective once social democracy fails to implement the programme for which the workers fought. This concept was theorized in 1938 by Leon Trotsky himself in his book The Transitional Programme, the Death Agony of Capitalism and the Tasks of the Fourth International ${ }^{14}$ that served as a basis for the programme of the Fourth International, founded the same year. Even though this idea dates back from before the Second World War, it is still highly regarded and used by most Trotskyist groups today throughout the world. In 2010, Peter Taaffe wrote:

The need for a transitional programme in this era arises from the mixed consciousness of working-class people. This consciousness will be shaken and changed by the march of events. But the development of a rounded-out socialist consciousness, firstly of the most politically developed layers and then of the mass of the working class, can also be enormously facilitated by a transitional approach and programme. This provides a bridge from the consciousness of working people today to the idea of socialist change. ${ }^{15}$

16 However, it has to be kept in mind that this was probably not only a tactical move. Trotskyists stand for the improvement of the condition of the popular classes and as such, their support for Jeremy Corbyn should not only be examined from a tactical perspective. Jeremy Corbyn opposed the disciplinary measures taken against Militant and its members in the 80s and 90s. For example For example in a letter Jeremy Corbyn and Bernie Grant wrote to the Socialist Campaign Group of Labour MPs on July 25th 1991, members of the group are asked to "send letters of support concerning the cases of Dave [Nellist] and Terry [Fields], and against the witch hunt of political views to the National Executive". ${ }^{16}$ Even though Jeremy Corbyn was not a member of Militant and never contributed to the paper, when he was elected as leader of the Labour Party, the 
Socialist Party was eager to share numerous pictures in which he and Dave Nellist (a former Militant MP and a leading figure of the contemporary Socialist Party) were seen walking and demonstrating together.

The Socialist Party manifesto does not only present a programme but also devotes extensive parts to analysis of the Labour Party. In the document, the two-party analysis is formulated that way:

Never before has it been so clear that Labour is two parties in one: a potential antiausterity party around Jeremy Corbyn, and a pretty fully formed pro-capitalist party around the Blairites. The pro-capitalist wing will never give up attempts to strangle a new anti-austerity party. Eleven Labour MPs voted against a general election. 100 of them didn't bother to vote! The arch-Blairites are determined to wreck Corbyn's chances of winning a general election. ${ }^{17}$

Putting aside the fact that it imay appear ironic for a fully formed party like the Socialist Party to comment on the organisation of the right-wing of the Labour Party into an allegedly fully formed pro-capitalist party, it is nonetheless interesting to observe that this paragraph appears in the column "capitalism - a system for the billionaires". As such, for The Socialist, wthe problem is both a question of ousting the Conservative Party from government and of ousting the right wing from the Labour Party. The column concludes in an equally interesting manner:

No more concessions should be made to them... We need a party that stands in the interests of the working class, all suffering austerity, and the environment - not the billionaires ! ${ }^{18}$

19 These two final sentences rely on an ambiguity that is highly characteristic of the Socialist Party's stance during this election. These sentences appear after a harsh criticism of the right-wing of the party, but are included in a column aimed at capitalism, meaning that the lines between the right wing of the Labour Party and the party of the capitalist class - the Conservative Party - are blurred. The conclusion brings up the idea of party building once again: is the party of the working class, demanded by the Socialist Party, the Labour Party or a new party of the working class, as had been evoked in previous party communications? This ambiguity is strategically interesting because it serves a dual purpose: campaigning with the Labour Party and campaigning for the Labour Party.

The other materials produced by the Socialist Party follow this pattern. A total of eight official posters were produced for the occasion and none actually mentions the Labour Party. They all feature the logo of the Socialist Party, its colour scheme (red on white) then exclaim "Tories out! Corbyn can win on socialist policies" in big letters in the centre, with a young woman raising her fist next to the main slogan. At the bottom of the posters the website address of the Socialist Party is shown. The eight variants of the poster consist of this frame with a different demand under the title such as the standard "Fight to save our NHS. Stop all cuts and privatisation. End low pay now" or "Fight for $£ 12$ an hour minimum wage now. End zero-hour contracts" or even very specific issues like "Solidarity with CWU postal workers". The message of support towards the CWU (Communication Workers Union) is significant: Bernard Roome, a former CWU National Executive Committee member, is a member of the Socialist Party, and one of the main fields of recruitment of the Party is the trade unions. ${ }^{19}$ More interestingly one poster distanced itself from Labour-compatible demands as it asks to "Fight for a pro-worker, internationalist, anti-racist Brexit". The official stance of the Labour Party, principally pushed by its moderate wing, was a second referendum. The 
Socialist Party was always opposed to the European Union ${ }^{20}$ and has always campaigned in favour of Brexit on a socialist basis. It is no secret that Jeremy Corbyn is and always has been a Eurosceptic ${ }^{21}$ but was forced to compromise on the Brexit issue with his party. Raising the issue of Brexit is a means for the Socialist Party to posture as true Corbynists with the working-class basis of the Labour Party of whom the majority voted voted in favour of Brexit. The tactic is dual: seducing the Working Class and appropriating their position by rallying them to the Socialist Party as the true left party of Brexit, thus pushing the fight with the right wing of the Labour Party further. The manoeuvre places the Socialist Party more in line with the leadership of Jeremy Corbyn and the mass movement that led him to this leadership than some other strands of the party itself. contribution for the campaign itself. The Socialist has been explicitly titling its edition in favour of a general election since April $18^{\text {th }}, 2018$. Just like the manifesto of the Party, a number of the editorials and articles of the paper were devoted to the fight inside the Labour Party against its right wing. On August $8^{\text {th }}, 2018$ the headline was "Tories and Blairites must go", one month later, on September $5^{\text {th }}, 2018$, it was "Tories Out! Blairites Out!", two weeks further, on September $19^{\text {th }}$ it was "Blairites must go!". In 2019, the headlines stopped attacking openly the right wing of the Labour Party with only one issue bearing the headline "Tories out, Blairites out", on February $20^{\text {th }}$. However, numerous articles explored this idea. For example, on the October $31^{\text {st }}$, right after the announcement of the snap election, The Socialist published two articles against the right-wing of the Labour Party. The first was the editorial entitled "Anti-Austerity, Socialist Policies Can Be a Winning Formula" in which we can read analysis such as this :

Corbyn and the Labour lefts bear a big share of the responsibility for this. Their endless attempts to compromise with the pro-capitalist Labour MPs have - as we warned - done nothing to stop the Blairities trying to undermine Corbyn. Instead, it has resulted in his antiausterity message becoming almost inaudible. ${ }^{22}$

In the same issue of the paper stands a column entitled "Opinion: The Labour Party is structured to block left councillors"; the article was written by Peter Redfarn, a member of the Labour Party, thus giving it more credibility. ${ }^{23}$ Conveniently placed next to this article, stands an advertisement for a book entitled In Defence of Trotskyism making the page present both the problem (the structure of the Labour Party) and the solution (Trotskyism).

To understand the relevance of the paper in the Socialist Party action we need to understand the practices of Trotskyism. The newspaper is not an end in itself and isnot only an agitational paper. It has several functions that explain why Trotskyists usually stick to newspapers instead of online ones that would be less costly and time consuming for such small structures. The newspaper is conceived as a fully-fledged tool for the activist. It is usually sold from hand to hand, subscriptions are not really encouraged. A common practice for members of the Trotskyist party is to sell the paper on stalls, conveniently placed in a city (near a market for example). They build the stall so that the slogans of the party are easily read on it. The paper here serves as a pretext to engage in conversation with people, build links with them and build local workers' solidarity just as the petitions on local issues are usually there for ${ }^{24}$ The paper also covers industrial or company struggles because this facilitates engagement on picket lines: the objective is educational, agitational but also tactical. 

left ideas were dominant in the manifesto of the Labour Party that was nicknamed "the longest suicide note in history" by one of its Members of Parliament, Gerald Kaufman. The manifesto of the party in 1983 was very much influenced by Militant who managed to push some of its demands into it such as nationalisations, unilateral nuclear disarmament, wage increases, pensions increases, withdrawal from the EEC, the nationalisation of "one or more" banks, and the suppression of the legislative powers of the House of Lords.

However, the comparison between the general election of 1983 and that of 2019 shows more differences than similarities, especially in the role played by the Trotskyists. First of all, in 1983, Militant was not recognised as a party, but as a tendency within the Labour Party. Militant had no members but only supporters, as it was not a party but a paper. ${ }^{27}$ It had a network of activists that were so well organised that they were able to have a decisive influence over the Labour Party conference; in 1983 because the two main dominant groups in the Labour Party (Militant and Tribune) were radical, they managed to shape the manifesto of the party. Militant's entryism has not always been understood properly by commentators and the breakaway from the Labour Party, which its editorial board was planning, was certainly not on a short-term perspective. The Trotskyists were in the Labour Party and intended to stay in it for a while. The perspective of a split was subordinated to the condition of a revolutionary situation and generalized disillusion of the workers in the Labour Party. Only at this point would a split happen. In 1983, this was not the case and Militant supporters were full-fledged members of the Labour Party with no intention to split from it in the years to come.

Numerous comparisons between Militant and Momentum have been made by the press and political commentators. However, their nature is different: Momentum had no other purpose than bringing Jeremy Corbyn to power and wanted to implement social and economic change through a democratic socialist process. As such, for Momentum, 
the elections are an end in themselves. On the other hand, the Trotskyists in 1980 were considering elections and the coming to power of Labour as a means for the bigger picture that was proletarian revolution.

As such, the comparison between the elections of 1983 and 2019 makes little sense. Momentum is in no way similar to Militant, either in terms of objectives (election vs revolution) or structure (pressure group vs entryist group). The heir to Militant, the Socialist Party, is clearly identified by the Labour Party members and it struggles to exist in their eyes. The other heir to Militant, Socialist Appeal (what reamined of the entryists) counts a couple hundred members, while back in 1983 Militant could boast thousands of sympathisers and two members of parliament, a situation which led Michael Crick to describe it as "Britain's fifth most important political party". Its influence was strong enough for it to win the position as representative of the Labour Party Youth Socialists (which it dominated) from 1972 up to the expulsion of the tendency from the Labour Party in 1986. ${ }^{28}$

\section{Conclusion: Trotskyism inside out}

30 Was the intervention of the Socialist Party detrimental to the campaign of Jeremy Corbyn? This question can barely be answered as it is impossible to measure the direct impact of the Socialist Party on the Labour campaign. Nevertheless, this question is interesting in the sense that it brings to the foreground two others. Firstly, it raises the issue of the left-wing nature of the Labour Party campaign and its responsibility in the defeat, said to be the worst the party has had since 1937. Secondly, it raises the question of the viability of the contemporary Labour Party as a recruitment ground for Trotskyists.

31 The responsibility of the radical left orientation of the Labour Party in its 2019 defeat needs to be qualified. The right of the party was prompt to point its finger at the socialists by saying 2019 was even more a total defeat than 1983 . However, data seem to indicate that even if the number of seats obtained by the party was inferior, it performed, overall, better than in 1983 especially when compared to the Conservative Party in the vote share. ${ }^{29}$ Moreover, in 2019, the popular vote for the Labour Party stood above the 10 million mark (10.3 million votes) as it did in 2017 (12.8 million votes) on an even more radical platform. The 10 million mark had never been achieved since the 2001 general election.

The main reason for the defeat of the Labour Party in 2019 is arguably (and in any case is understood as such by Socialist Party activists) ${ }^{30}$ the Brexit issue, with a party policy standing between Leave and Remain, and a party leader unconvinced on the issue. The party lost the vote of the working classes that voted massively in favour of Brexit in 2016 andwho felt betrayed by the stance taken by Labour. This resulted in letting Boris Johnson dominate the campaign by being the only strong leave candidate. As such, it is not the radicality of the Labour Party Manifesto that caused the defeat but it might be the struggle within the Party that resulted in Jeremy Corbyn's compromise with the remainer faction through the integration of the people's vote strategy.

What does this mean for the Trotskyists of the Socialist Party? It seems that the four years of the Corbyn experience reoriented the heirs of Militant towards the Labour Party. The day after the election, the Socialist published an article inviting its readers to "Blame the Blairites. Kick out the pro-capitalist saboteurs. [And to] Refound Labour 
as a mass democratic workers' party with socialist policies" and - paradoxically - to "Join the fightback! [And] Join the Socialist Party!". It seems the Socialist Party, which could be defined as a stable group for a Trotskyist organisation, ${ }^{31}$ is re-evaluating its nature as a fully independent party aiming at becoming a mass organisation or going in election under ad-hoc alliances. Instead, the election of 2019 seemed to have brought back the old strategy of an existence as an educational group, aiming at training cadres able to lead the social movement. The Corbyn era proved that the Labour Party was a fertile ground for socialist ideas, and the reaction of the right wing against these ideas give the Trotskyists of the Socialist Party a foil which enables it to exist back as the champion of the left wing of the party. The failure of Momentum to keep its own momentum with the failure of Rebecca Long Bailey to secure the leadership of the Labour Party might leave a breach open for the Trotskyists to engulf again in the battle of the Labour Party.

\section{BIBLIOGRAPHIE}

Bensaid Daniel, Les trotskysmes, (Paris : Presses universitaires de France, 2002).

Crick, Michael, The March of Militant (London, Faber \& Faber, 1986).

Grant, Ted, History of British Trotskyism, (London, Wellred Publications, 2002).

Kelly, John, Contemporary Trotskyism: Parties, Sects and Social Movements in Britain (Oxon, Routledge, 2018).

Labour Party Rule Book (2019).

Shaw, Eric, Discipline and Discord in the Labour Party (Manchester University Press, 1988).

Smith, Evan, Worley M. (Eds), Against the Grain: the British far left from 1956 (Manchester University Press, 2014).

Smith, Evan, Worley M. (Eds), Waiting for the Revolution: the British far left from 1956 (Manchester: Manchester University Press, 2017).

Taaffe, Peter, From Militant to the Socialist Party (Croydon: Socialist Publications, 2017).

Trotsky, Leon, L'agonie du capitalisme et les tâches de la IV internationale, Programme de transition, suivi de «discussions avec Léon Trotsky sur le programme de transition » (Pantin : Les bons caractères, 2013).

Archives of The Socialist : < https://www.socialistparty.org.uk/main/The_Socialist> accessed 10 May 2020.

Leaflets published by the Socialist Party : < www.socialistparty.org.uk/leaflet> accessed 10 May 2020.

Socialist Party Podcast : < https://soundcloud.com/socialismpodcast>accessed 10 May 2020.

Peter Taaffe speech at Socialism $2019:<$ www.youtube.com/watch?v=kiRXqcGIh-o> accessed 10 May 2020. 


\section{NOTES}

1. Daniel Bensaid, Les trotskysmes, pp.78-79 (Paris, Presses universitaires de France, 2002).

2. Vladimir Lenin, Collected Works, 4th English Edition, Vol.31, Speech on Affiliation to The British Labour Party, August 6 pp.213-263 (Moscow, Progress Publishers, 1965).

3. Leon Trotsky, "Once again the ILP", New International, Vol.3 No.1, February 1936, pp. 5-10 https://www.marxists.org/archive/trotsky/1936/xx/ilp.htm consulted 20 April 2020.

4. Ted Grant, History of British Trotskyism, (London, Wellred Publications, 2002) p. 75.

5. Peter Taaffe, From Militant to the Socialist Party (Croydon, Socialist Publications, 2017).

6. Phil Burton-Cartledge, "Marching Separately, Seldom together : the Political History of Two Principal Trends in British Trotskyism, 1945-2009" in Evan Smith, Matthew Worley (eds), Against the Grain: the British Far Left from 1956 (Manchester University Press, 2014)

7. Socialist Party manifesto, Let's get the Tories out, leaflet issued on 27 November 2019.

8. Letter from Peter Taaffe to Jennie Formby, 6 April 2018, reprinted in The Socialist, 20-26 September 2018.

9. Hanah Sell, "May and Tories must go! Organise, strike, resist, to fight for Corbyn's policies" https:// www.socialistparty.org.uk/articles/25615/09-06-2017/may-and-tories-must-go consulted 6 February 2020.

10. See Eric Shaw, Discipline and Discord in the Labour Party (Manchester University Press, 1988)

11. “Constitutional rules, Clause II.5.A", Labour Party Rule Book 2019, https://Labour.org.uk/wpcontent/uploads/2019/04/Rule-Book-2019.pdf consulted 08 May 2020.

12. "Editorial: The Struggle to Transform Labour", The Socialist, 20-26 September 2018.

13. Peter Taaffe speech at Socialism 2019, 2 November 2019, London. https://www.youtube.com/ watch?v=kiRXqcGIh-o consulted 30 April 2010.

14. Leon Trotsky, L'agonie du capitalisme et les tâches de la IV internationale, Programme de transition, suivi de "discussions avec Léon Trotsky sur le programme de transition ", (Pantin, Les bons caractères, 2013).

15. Peter Taaffe, "New Introduction to the Transitional Programme", June 2010 https:// www.socialistworld.net/2010/08/21/theory-new-introduction-to-the-transitional-programme/ consulted 02 Mai 2020.

16. Letter from Jeremy Corbyn and Bernie Grant to the Socialist Campaign Group of Labour MP, 25 July 1991

17. Socialist Party manifesto, Let's get the Tories out, leaflet issued on 27 November 2019.

18. Ibid.

19. Before supporting the Labour Party of the Corbyn Era, the Socialist Party was taking part in the elections as a component of TUSC (Trade Unionist and Socialist Coalition), an alliance between the Socialist Workers Party, some unions which were not affiliated to the Labour Party and itself. Trotskyist activists are usually members of a union as the class struggle is meant to happen primarily on the workplace.

20. The anti-EU stance of the Socialist Party does not mean it is against European construction. On the contrary, as an internationalist party, it calls for the construction of the Socialist United States of Europe.

21. See Mark Pack's blog compiling Jeremy Corbyn's voting record and stances on the European Construction: https://www.markpack.org.uk/153744/jeremy-corbyn-brexit/ (consulted 20 March 2020).

22. "Editorial: Anti-Austerity, Socialist Policies can be a Winning Formula", The Socialist 31 October - 6 November 2019.

23. Ibid.

24. John Kelly, Contemporary Trotskyism: Parties, Sects and Social Movements in Britain (London, Routledge, 2018). 
25. Birmingham, Bradford, Bristol, Cardiff, Coventry, Exeter, Leeds, Leicester, Liverpool, London, Reading, Sheffield, Southampton, Stoke, Swansea, Wakefield, Wolverhampton and York.

26. The post is accessible on the Instagram account of the Socialist Party: https:// www.instagram.com/p/B5Dbytopz_o/ (consulted 05 May 2020).

27. Christopher Massey, "The Militant Tendency and entrism in the Labour Party" in Evan Smith, Matthew Worley (eds), Waiting for the Revolution: the British Far Left from 1956 (Manchester University Press, 2018)

28. Michael Crick, The March of Militant, pp. 64-65 (London, Faber \& Faber, 1986)

29. In 1983, the Labour Party secured 0.6 votes for each conservative vote while the ratio was of 0.75 vote Labour for 1 vote conservative.

30. The Socialist Party podcast is instructive in this way and shows that there is a strong sense within the party that the radical manifesto of the Labour Party has nothing to do with its defeat. See ttps://soundcloud.com/socialismpodcast/53-tories-return-stand-firm-for-socialist-policies (consulted 5 mai 2020)

31. Since 1957 and its first incarnation in the Revolutionary Socialist League, the Trotskyist group has only know one major split, in 1992, over whether Militant should leave the Labour Party or not. Roughly ten percent of the organisation split to stay inside the Labour Party under the name Socialist Appeal and led by Ted Grant. The majority, led by Peter Taaffe, which left the Labour Party is the one that restructured in the Socialist Party in 1997.

\section{RÉSUMÉS}

Les élections législatives de 2019 au Royaume-Uni furent finalement celles qui amenèrent la chute de Jeremy Corbyn et un retour du parti travailliste vers une ligne politique moins radicale. Cette élection présenta également une particularité pour l'un des deux plus vieux partis trotskystes britanniques : le Socialist Party. En effet, le parti héritier de la tendance "Militant" des années 1980 a décidé de ne pas présenter de candidats à cette élection et de soutenir officiellement la campagne de Jeremy Corbyn. Cet article s'emploiera à retracer le lien historique unissant le Socialist Party au parti travailliste. Il explorera également les modalités matérielles comme idéologiques du soutien du Socialist Party envers le Parti travailliste. A partir de ceci, nous examinerons comment la campagne trotskyste servait plus ses propres objectifs politiques révolutionnaires qu'elle ne constituait un engagement réel envers le Labour. Cet article examinera également la comparaison souvent faite par les médias et opposants à Jeremy Corbyn entre les élections de 1983 et de 2019. Le rôle des trotskystes infiltrés d'alors et de Momentum actuellement ainsi que les raisons de leur engagement respectif seront également étudiées.

The UK 2019 general election was ultimately the one which brought Jeremy Corbyn's downfall and a shift back from the radical to the soft left in the political line of the Labour Party. This election presents a singular character for one of the two oldest Trotskyist parties in the UnitedKingdom: the Socialist Party. Indeed, the Trotskyist party, heir to the Militant Tendency of the 1980s, decided not to stand any candidates at this election and to officially support Jeremy Corbyn's campaign. This paper will retrace the history linking the Socialist Party to the Labour Party. It will also explore the modalities of the Socialist Party's support for the Labour Party in both its material and ideological aspects. From this, it will show how this campaign was ultimately more a campaign to serve revolutionary objectives, than a genuine campaign for the 
victory of the party led by Jeremy Corbyn. This paper will then proceed to examine the comparison often drawn by the media and the political opponents of Jeremy Corbyn between the elections of 1983 and 2019 by examining the role played by the Trotskyists then and Momentum now, the reasons of their support to Labour an the results obtained by each.

INDEX

Mots-clés : élections législatives, trotskystes, Parti travailliste, Momentum, Militant, entrisme Keywords : General Election, Socialist Party, Trotskyism Labour Party, entryism, Momentum, Militant 